\title{
The figure of the woman in the Protoevangelium and the dispute of the sexes: An analysis on Genesis 3:15
}

Canete, Jonathan James O. $\triangle$

De La Salle University, Manila

La Salle College of Antipolo, Philippines (Ncanete976@gmail.com; Jonathan_james canete@dlsu.edu.ph)

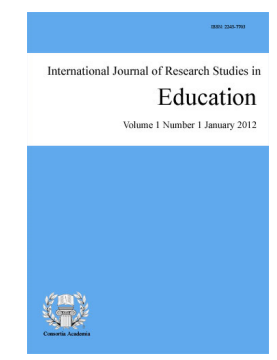

ISSN: 2243-7703 Online ISSN: 2243-7711

OPEN ACCESS

\section{Abstract}

The book of Genesis tragically narrates the story of the fall of humanity from God's grace through Adam and Eve's sinful disobedience. This catastrophic event that marks the presence of corruption in man's heart would not happen if not because of the woman. By blaming Eve, Adam explicitly magnified the female figure's weakness and accused her of being detrimental to the male figure's inherent perfection. The accusation of Adam continues up to the present state of humanity. Femininity is only considered as the second sex, while masculinity has been elevated to the altar of perfection. The present culture in many regions and countries exults patrimony while belittling femininity. This social condition is deeply manifested in how many interpreted the scripture, particularly the fall narrated in a unique way in Genesis 3:15. Many interpreters of the narrative of the fall still follow the "Adamic" mentality of blaming the woman as the primary agent of the fall. On the other hand, many would also embrace the patriarchal point of view regarding the Protoevangelium focusing on the seed rather than the woman's figure as the primary agent in God's salvific plan. Nevertheless, amid all these interpretations, the writer's intention is still clandestine in the wonders of words and syntax of Genesis 3:15. Why he/she places the figure of the woman first before the seed, this study is an attempt to decipher the intention of the sacred writer and to redeem the figure of the woman who had been deeply abashed by the lingering patriarchal culture and patriarchal exegesis.

Keywords: Protoevangelium; woman; Exegesis; dispute; sexes 


\section{The figure of the woman in the Protoevangelium and the dispute of the sexes: An analysis on Genesis 3:15}

\section{Introduction}

One of the most dramatic scenes, out of the many, is probably the fall of man in the Old Testament narratives. There, one can see that man, because of his/her inner desire to be someone more significant than what he/she is created for (Gen. 3:6), fall out of God's grace and start to notice their natural nakedness (Gen. 3:7). It is plausible to note that the word "sin" is not mentioned in the scriptural account of man's fall. However, its first manifestation can be read in chapter four, in the story of Cain and Abel (Paule, 2017). Though the word sin is not present in the account of the fall, its essence remains; falling out of God's grace in the aftermath of sin, and the corruption of man's inner innocence and his affinity towards goodness have been deeply affected (Jackson, n.d.). One can stipulate that such corruption in man create both spiritual and physical division between God and man, and between man and his/her kin. This observation is deeply manifested in Genesis 3:8 where both the man and woman had hidden from the presence of God as He was looking for them; sin hides man from God; such hiding is an indication of not just one's physical nor spiritual detachment from something good, but it also means that one had done something terrible to the One who had been immensely good.

The guilt that humanity's first parents had experienced during the fall, shown first in the very act of hiding, and, second, after the fall, which was manifested in the sufferings of childbearing and the subjugating philosophy of patriarchy, leaving the woman in despair if not in constant competition with patrimony (Gen $3: 16$ ). This also includes the severity of human labor for one to survive (Gen 3: 18-19). Therefore, Genesis 3 is about man's turning away or hiding away from God and the guilt that he/she harbors in his heart. However, the story does not just revolve around man's demise; rather, it pertains as well to a benevolent God. It is not only about man's fall, but also about God's graciousness and merciful love (Vawter, 1937, p. 67). The fall was caused by man with all his limitations and weaknesses, but restoration is an act of God in and through man. The prime mover of the entire drama of the fall, aside from the serpent that played the role of a tempter, is the woman who was also instrumental to the entire process of salvific restoration of humanity and the entire creation. Furthermore, in Genesis 3:15, right after the narration of great disappointment and disobedience, God made a solemn promise to the serpent and the entire humanity that there will be a woman, whose progeny she bears, will strike the head of the serpent. Though God refers to the offspring of the woman, one may not take away the vital role the mother of that offspring plays in the story of man's redemption. This study, therefore, is an elaboration and an exegetical analysis on the critical role and possible identity of the woman in the literary piece of Genesis 3:15, that most scholars of the scriptures tend to or accidentally superintend by focusing on the masculine figure.

This exegetical analysis employs a characterization methodology in exposing the hidden worth of the female figure that exegetes tend to overlook or even oversimplified. Likewise, an inductive claim would be asserted in defense of femininity in a cultural society wherein the masculine figure dominates. Throughout the paper, one can notice the struggle and conflict of the sexes - one tries to dominate, while the other asserts equality. In the end, the key for a harmoniously grounded relationship is not dominance but a relationship of commensality.

\subsection{Objective of the study}

The general objective of this study is to deconstruct the intellectual misunderstanding that surrounds the figure of the woman in Genesis 3:15 as someone that causes the great fall of humanity. On the other hand, the specific objectives behind this study are to create awareness that the female figure, like its dominant counterpart, was divinely empowered by God in the scriptures to be part of the entire salvific plan. Hence, the figure of the woman should not be categorized as a secondary sex. 


\section{Methodology}

This study is an exegetical attempt in shedding light behind the mystery of the figure of the woman in Genesis 3:15. Exegesis is a systematic and scientific way of finding meaning behind the text, without falling into the death-trap of adding, negating, fabricating, distorting, nor concealing the truth that lies in the text (Filson, 1948, p. 212). Hence, exegesis is a method of unearthing the meaning that lies in the text itself. This study employs the exegetical method particularly focused on syntax and on grammar as its scholarly means in approaching the issue (Stevens, 1889) on the figure of the woman in Genesis 3:15 and how this same figure is related with the modern-day struggles of women.

\section{Discussion}

\subsection{Structural and syntactical analysis of Genesis 3:15}

If one will read Genesis 3:15, one would quickly notice that the focus of the entire passage is on the word Zerah or "seed." For example, some scholars like Alofarin Olutunde Ojewole, who wrote an entire dissertation about Gen 3:15, focusing the gaze and scholarly attention on Zerah. Like Ojewole, the biblical exegete Jared M. August (2017) argues that the protoevangelium, or "the first gospel" revolves around the pronouncement of God concerning the forthcoming of a "seed who will bruise the head of the serpent" (p. 46). This, in itself, sets the entire messianic expectations in the Old testament. In other words, the protoevangelium sets the mood of an all-inclusive expectation of a person who would redeem humanity from its fallen state. The biblical scholar Walt C. Kaiser (1995) exegetically affirms this by saying that,

"Genesis 3:15 has commonly been called the protoevangelium (the "first gospel") because it was the original proclamation of the promise of God's plan for the whole world ... it gave our first parents a glimpse ... of the person and mission of the one who was going to be the central figure in the unfolding drama of the redemption of the world. The "seed/offspring" mentioned in this verse became the root from which the tree of the OT promise of a Messiah grew" (p. 37-38).

Therefore, biblical scholars focused their gaze on the seed's image concerning the promise of a messiah. However, the semantics and the grammatical structuring of the text speaks not only of the seed but primarily of the woman. Although the text's sense revolves around the Zerah concept, the semantics of the text speaks of the critical role of the woman in the entire salvific promise. The structure in Genesis 3:15 speaks of God's salvific proclamation after the undesired, catastrophic, and seemingly unprecedented act of humanity's first parents. This proclamation consists of two different but interrelated assertions. The author has distributed these proclamations to the verse's two phrases. The first assertion is an allusion and an avowal to the centrality of God's figures, the serpent, and the woman in the entire salvific promise. On the other hand, the second phrase speaks of a shift not only in tone but also of grammatical gender and importance; the author suddenly alters his/her gaze on a masculine figure representing the seed or the offspring of the woman. Though signifying two different, yet interrelated figures, the entire verse categorically suggests a continuum of two phrases, forming one compound sentence.

The first phrase, "I will put enmity between you and the woman, and between your offspring and hers," speaks of the fist proclamation, that follows the S-V-IO-DO grammatical pattern. The grammatical pattern would place the woman's figure to the pedestal of importance when talking about the entire salvific proclamation. In the rule of interpretation in grammatical syntax, the direct object (DO) is inferred as either the receiver or the doer of the action. In contrast, the indirect object (IO) complements or supports the DO (Shrives, n.d.). Furthermore, the text's main clause in the first sentence contains the S, V, DO, and IO, while the "subjects" of its subordinate clause points to the sense of the main clause, is just an allusion to the first sentence. This is quite contradictory because of the emergence of the ";" The semicolon made the sentence or the phrase an independent one (Grammarly, 2019). Interestingly speaking, even though the sentence that proceeds the semicolon ("he will strike 
your head, and you will strike his heel") is grammatically independent and syntactically correct, the sense, however, takes a dependent form; the logic speaks of the sense in the scriptural text's first sentence, specifically the main clause ("I will put enmity between you and the woman..."). This makes the second sentence appears to be a dependent clause. To have a clear view of this concept, one needs to consider this illustration of Genesis $3: 15$.

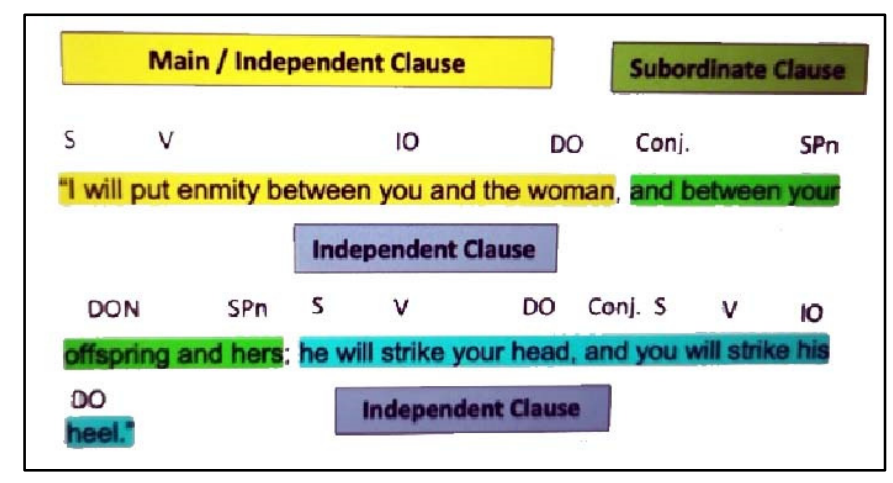

Illustration 1. Syntactical application and analysis

The illustration above shows the main, and at the same time, the independent clause of Genesis 3:15. It also contains within itself the S-V-IO-DO grammatical pattern, where the word "I" is S, and "will put enmity" is V, while "you" is IO, and "woman" is DO. The syntactical analysis of the main clause speaks of the DO as the very instrument of S in justifying the V for IO. In other words, the woman plays a dynamic role in bringing and fulfilling God's promise for humanity. Therefore, the woman is in the active mood, quite contrary to the claims of the patriarchal biblical exegesis that qualifies the "offspring" only as the active player in the entire salvation history and would equate the figure of the woman only as a passive observer. Hence, the word "offspring" is in the current mood, while the word "woman" is passive.

Nevertheless, the illustration reveals that the offspring's figure is the DON (Direct Object Noun) of the subordinate clause. The subordinate clause qualifies the proposition on the centrality of the figure of the woman in the protoevangelium, that the figure of the offspring as a direct object noun, posited either be the offspring of "your" (Subject Pronoun), about the serpent on which God directed the salvific proclamation or the offspring or the seed of "hers" (Subject Pronoun), about the figure of the woman, is, therefore, just a referential word. The enmity that the subject of the Genesis 3:15 would place is first between the woman and the serpent, then the dependent clause speaks of the enmity between their respective offspring.

However, the writer suddenly shifts his attention to another figure. The second sentence in the same verse speaks of the manner on how such enmity would exist, but it is quite puzzling to know that even though the sentence speaks of what it precedes, for the grammatical punctuation mark semicolon is present that makes the entire sentence, though grammatically and syntactically independent, would become a dependent one, it has, in itself, a different subject that would justify the verb of the subject in the first sentence. In other words, the "how" of the enmity in the first sentence is satisfied by the subject in the second sentence. The woman's figure should do the justification of the first sentence verb; however, in the second sentence, the justification of the enmity is being altered, not anymore by the woman but by a masculine figure. This, as it were, suggests the literary device that the author used is a different literary device. The author juxtaposes the role of the woman and the role of the masculine figure in the second sentence.

On the other hand, the rhetorical device used is an allusion. Even though the author of Genesis 3:15 used the contrast literary device, the second sentence of the text is still a stipulation of the first sentence due to the semicolon's existence. As mentioned, biblical exegetes and scholars focus on the second sentence, dismissing the woman's figure in the entirety of the text. Arguably speaking, the S of the second sentence and its IO does not necessarily refer to a masculine figure. The Talmud of the Rabbinical Judaism would argue that the subject in the 
The figure of the woman in the Protoevangelium and the dispute of the sexes: An analysis on Genesis 3:15

second sentence that will bruise the head of the serpent is symbolically applied to Adam as a representational word or character for humanity (Neusner, 1984, p. 165). Here, humanity is being equated with the masculine figure. However, the Christians would categorically identify this Adam of the Jewish Talmud, not as a representational figure for the entire humanity, but as an association to the figure of Christ as the new Adam. As the "new Adam," St. Irenaeus would argue that through the figure of the woman, new humanity would emerge in and through Christ as the "seed of the woman," the firstborn of all creatures, by which the entire humanity is restored and renewed (McDowell, 1999, p. 334).

This suggests an "old Adam" and former humanity, which fell from the creator's grace. Both interpretations revolve around a masculine figure, the figure of Adam as humanity and the figure of Adam as Christ and would extoll a patristic way of looking at reality. However, the semantics of Genesis 3:15 elevates the figure of the woman as someone who will be instrumental to the entire salvific plan. It is only the woman's figure, aside from God and the serpent, who had clearly been stated semantically. The sense behind the male figure then is open for cultural interpretation, with an unconscious adaptation of the principle of patriarchy. Moreover, Genesis 3:15 contains within itself proclamation after proclamation. The first proclamation is all about the figure of a woman, who was predetermined by God to play an essential role in the entire salvific plan. In contrast, the second proclamation suddenly speaks of a masculine figure who would bring God's plan into reality. The spotlight is not anymore on the figure of the woman. However, it is focused on the masculine figure whom biblical scholars associated as the seed or the offspring mentioned in the first proclamation.

\subsection{Literary context and the socio-historical context}

The proclamation made by God in Genesis 3:15 is a reaction and countermeasure to what had happened before the very proclamation itself. In other words, Genesis $3: 15$ is a reaction to Genesis 3:1-6, the fall narrative. The writer of Genesis 3:15 first situates the readers within the fall of man, wherein humanity's first parents fell from God's grace, and so the entire creation. Hence, the immediate context by which Genesis 3:15 positions itself is within the greater context of humanity's fall. In Genesis 3:1-6, the narrative of the fall, the writer was able to convey one of the fundamental truths about humanity - that even though the human race is a race divinely ordained by God to be great, for humanity is created in God's very image and likeness and thus endowed with intellect and the capacity for self-determination (Jewett, 1976), This prodigious capacity to be what one wants to be through one's access to free choices is, at the same time, the very source of one's demise. In this case, the writer brings his/her reader to a realization that humanity is susceptible to fall through the capacity for self-determination. In this sense, the glory that man receives "is a mutable glory." It is a glory which involves a choice, and the choice implies the awful possibility of failure and misery. Man is created, in other words, able not to sin (posse non peccare), as Augustine long ago observed. If he proves obedient, he will be confirmed in righteousness, unable to sin (non posse peccare), a state of beatitude symbolized by the tree of life amid the Garden (Gen. 2:9). However, if he fails the pro-bation, if he is disobedient, he will be confirmed in sin, not able not to $\sin$ (non posse non peccare). This loss, in other words as Jewett argues, will be irrevocable; it will mark him for death (Gen. 2:17). The greatness of humanity, therefore, lies in his obedience to the will of his creator.

However, the writer communicates that humanity had failed to set his will to that of the creator and used his/her freedom outside of what was mandated of him/her. Furthermore, interestingly speaking, the figure that was instrumental to the fall of humanity, is the figure of the woman, Eve. What could be in the writer's mind why he/she used the figure of the woman as an entry point for the corruption of humanity to exist? The biblical scholar David Guzik (2006) provided a possible explanation. He argues that "Satan brought his temptation against the woman because he perceived she was more vulnerable to attack. This is because she did not receive the command to not eat of the tree of the knowledge of good and evil directly from God but through Adam (Genesis 2:15-17)." This interpretation from Guzik makes no sense, for even though Adam had received the mandate directly from God, he still ate the forbidden fruit and directly disobeyed God. It makes no difference, whether Eve received the mandate either from God or from Adam, one thing remains: if Adam fell so shall, possibly, Eve. Such deduction is a form of injustice on the part of the woman that being a woman means being 
weak and worst, the cause of man's fall. The very idea is a strong accusation on the female figure, that because she caused the fall of the first Adam and the entire humanity, she should not be permitted to decide on her own, lest she will commit a terrible mistake, and for that, be governed by the prudent judgment of the male figure. Here, the woman is seen as a person who cannot make or even be allowed to decide on her own. She is closely tied-up with imperfections and the very image of the male figure connotes perfection; her decisions and way of living should be monitored by the male figure for her not to commit any mistakes.

There are many possible answers provided by different biblical scholars for a reason behind the writer's intention to place the woman's figure into a scenario where femininity signifies weakness, and masculinity signifies strength and idealism. However, it remains an open-ended book and a subject for further scrutiny as to the real intention. One thing is obvious, though the writer operates based on the protracted patriarchal culture, it is fascinating to notice that he/she placed the protoevangelium after the very narrative of humanity's fallen state, especially after the destruction and reduction of the feminine figure; after the worth of the female figure has been reduced in Genesis 3:6 and after the narrative of God's retribution, the author suddenly redeems the figure of the woman.

The theologian Mary Fairchild plausibly exposed the forgotten significance of Eve that patriarchy tends to ignore and dismiss. "God called the woman Ezer, which in Hebrew means 'help.' Adam named the woman Eve, meaning 'life,' referring to her role in the procreation of the human race," as Fairchild (2006) believes. Here, Mary Fairchild offers a revolutionary image of the woman's figure and redeems such from the delusions created by an androgynous society. She emphasizes that the term Eve does not merely mean "mother of all the living," but the word, itself, signifies life.

This idea of Eve signifying life should not be taken away with Fairchild's analysis, an analysis signifying Eve as a woman. Eve, being a woman is an Ezer; as an Ezer, Eve is not an instrument nor an inferior who is under the protectorate of the masculine figure, but an Ezer, a partner; someone of equal dignity with the male figure and someone who, like the masculine figure, could be an instrument by God in his entire plan. This could be seen in procreation. In procreation, both the masculine and feminine figures are used by God as instruments in bringing forth life; this makes both sexes as significant contributors who gain participatory status in God's creative act. Mary Fairchild added that Eve is Adam's helper in the process of procreation; she is "the one who would complete him and share equally in his responsibility for creation. She, too, was made in God's image, displaying a portion of God's characteristics. Together, Adam and Eve alone would fulfil God's purpose in the continuation of creation. With Eve, God brought human relationship, friendship, companionship, and marriage into the world" (Fairchild, 2006).

In this sense, Fairchild argues that the figure of the woman is not inferior and therefore, should be vanquished by and under the rule of the dominant male figure, for the former, having been taken out of Adam (Genesis 2:21), meaning, taken out from the bosom of humanity not from the male figure, postulating male dominance, means the figure of the woman is very much part of the same humanity that the male figure belongs too, and hence, possesses the same level of dignity and worth with the male figure. Equally, the chroma existing in the function of both sexes suggests not the aspect of superiority. However, instead, the real differences in function point out to the complementariness preponderant in both sexes. Hence, differences are bridges for the unity of both sexes, not avenues for further division and domination. In context, the writer was able to positively project the female figure as the male figure's "helper and partner" (Genesis 2:18). However, the interpretation coming from a patriarchal context and lenses delineates the worth and essence of femininity as a weak figure, and it's very weakness causes the fall of humanity. In this sense, a proper rereading of the fall narrative should be extracted to redeem the female figure and appear the intention of the writer of Genesis 2 and 3 on the woman's figure, which the patriarchal interpretation tend to move away.

The narration of Genesis 3 is all about the story of the fall and redemption of humanity. Humanity's fall from God's grace, as written in Genesis 3, is neither the responsibility nor all about the fragility of femininity. 
The figure of the woman in the Protoevangelium and the dispute of the sexes: An analysis on Genesis 3:15

However, it is all about the innate weakness of humanity in general. In his great work entitled the Leviathan, the philosopher Thomas Hobbes argues that the human person is by nature a selfish kind of being; he is like other creatures that operate based on the dictates of nature and the code of the jungle. Garrath Williams enumerated Hobbes' three main and compelling arguments regarding the natural sense of selfishness that man possesses. Hobbes thinks that (i) man "will compete, violently compete, secure the necessities of life, and perhaps make other material gains. (ii) He argues that we will challenge others and fight out of fear ("diffidence"), to ensure our safety. (iii) Furthermore, he believes that we will seek reputation ("glory"), both for its own sake and for its protective effects, for example, so that others will be afraid to challenge us," (Williams, n.d.). Hence, Hobbes notices that man will always do things solely to advance his interest and secure his position and existence in this world of competition. Though rational as he is, the human person is still very much part of nature and operates based on the dictates of nature. It is in this regard that the scholar John Warner (2016, p. 5) exclaimed that "Humans are divided beings." The only thing necessary for an individual is his self-gratification; the focus is on the "I" not on man's capacity for "thou."

The author of Genesis 3 was plausibly able to elucidate this tendency of the human person to exalt himself and preserve his existence by narrating the fall scene. The writer, in a sense, did not use the figure of Eve, to make the figure of the woman to be someone inferior. However, in close analysis, he/she intentionally uses the woman's figure as a representation for the entire humanity for the name Eve signifies "mother of all the living" (Genesis 3:20), or mother of humanity. The attitude that Eve displayed is the natural attitude of man, which is not natural, for by doing things in his way in preserving his existence solely, disregarding his capacity for otherness, he is stepping closer to his demise, thus the experience of the fall. In the narrative of the fall, the figure of the woman is the very representation of the entire humanity, and the fall of the woman is the fall of the entire humanity.

However, the story does not end in the fall. The writer in Genesis 3:15 flaunted the prominence of the figure of the woman in the entire salvation history that the seed of the woman, popularly referring to Christ, or the entire humanity, or even the congregation of the believer of the way, will be of curtailed value if not because of the figure of the woman. God, in Genesis 3:15, redeemed the entire humanity by redeeming the dignity of the woman. The protoevangelium is about the seed, but it is also about the story of the woman, whom God used to restore everything that had been disfigured by humanity's greed. The seed is nothing if not because of the woman's figure as the semantics of Genesis 3:15 would show. Therefore, reading Genesis 3:15 entails considering not only the speed but also the importance of the woman. Genesis 3:15 is a revolutionary verse written during the patriarchal time, within the context of patriarchy; it is a verse that advances the worth of women in a society where male dominance is evident. As early as the book of Genesis, though it is a myth written in Exodus's support, the worth of the female figure is being elevated and valued.

\subsection{The social outlook of the female figure}

History will tell the present generation that women during the ancient time were respected and even worshiped. Betty Schlossman and Hildreth York were able to expose the invaluable worth of the female figure, particularly during the time of the ancient civilization, where femininity was considered sacred. The female figure as a god had been extolled to their high altars. "In Egypt, for example, female deities continue to be represented and worshiped until the end of the late period (c.700 B.C-100), often incorporating important roles of women in human society" (Scholossman and York, 1976, p. 345). Like their Egyptian counterpart, the ancient Mesopotamians also places the female figure on their altars; the female God Inanna-Ishtar governs the paradigm of love; she is also considered the goddess of war. Egypt and Mesopotamia are just two of the many ancient civilizations that gave ample importance to the female figure. However, as time progresses, the female figure is removed from the pedestal and was alienated from society. The height of female alienation had transpired during the 19th century, especially in Europe and in North America, where "women and men were expected to fill separate spheres of society. Men were expected to live a public life, whether working in a factory or socializing with like-minded men in public places like clubs, meetings, or bars. On the other hand, women were usually 
expected to live largely homebound, taking care of cooking, cleaning, and child-rearing. Free time for women was not supposed to be spent socializing but doing other things related to the family's maintenance, from sewing socks to laundry" (Sailus, n. d.).

The female figure's worth is reduced to attending the needs of the family, serving its pillar, and doing domesticated chores. In other words, the female figure's sense of existence is that of the household while the male figure dominates the public sphere and the religious sphere. Most women in the bible, too, are not exempted from social alienation and the degradation of existential worth caused by a male-dominated culture; to be a woman in the biblical world, is to assist men in their ministry and do what exactly has been argued earlier. The transformation of a just and well-balanced society into an androgynous society has left the female figure vulnerable, and therefore, grappling for meaning, rights, and integral equality and opportunity.

This is the reason being behind the rise of the feminine and womanist movement all over the globe, principally in Europe, North, Central, and South America, where racial and sexual inequality was very much evident. Women began "protesting, attending political speeches... many of these women became vocal participants of the women's rights movement" (Sailus, n. d.). Women were becoming more aware of the oppressing state of the lingering and ubiquitous androgynous culture and started resisting and fighting for their rights. The voices of women are heard not only on the streets, and the alleys, but also in the realm of politics: the figure like Margaret Thatcher, Elizabeth Yates, Corazon Aquino, Angela Merkel, Queen Elizabeth had changed the position of women in the political arena; women also had their voice heard within the halls of the academia: scholars like Agnes Brazal, Miriam Defensor Santiago, Hannah Arendt, and Simone de Beauvoir, Srs. Mirasol Navidad and Aurea Arabit; the female figure was also recognized in the cathedrals of religion like Mother Teresa of Calcutta, Mother Angelica, and Dorothy Day. The prowess of the female figure started to reshape society and restructure cultures; However, the sense of androgyny is still strong in the social sphere. It does not anymore create a kind of stratification that alienates the female figure from society. Because of the female figure's unwavering free spirit, they have rediscovered and retrieved the forgotten worth of femininity in reconstructing society.

\section{Conclusion}

The spirit of Genesis 3:15 is evident in the ongoing fight of women and other genders who, in their uniqueness, have been maligned and disfigured by the society that wallows machismo as the basis for greatness. Genesis 3:15 empowers women and another gender. They can also be divinely ordained by God to participate and be instruments in recreating society; women, gays, lesbians, bisexuals, queer, etc. can do more and can contribute something worthwhile in society. If only they are heard and given a chance to prove themselves, the world will again be an oasis of equality and a new Eden, where each one is a family, not a stranger.

\section{References}

August, J. M. (2017). The messianic hope of Genesis: The Protoevangelium and patriarchal promises. Themelios: An International Journal for Students of Theological and Religious Studies, 42(1), 46-62.

Cengage. (n. d.). Redirection to equivalent. Retrieved November 21, 2019, from http://college.cengage.com/devenglish/broughton/focus_florida/1e/students/diagramming_basic/pattern 3.pdf

Fairchild, M. (2006, November 15). Meet Eve: First woman, wife, and mother of all the living. Learn Religions. Retrieved November 26, 2019, from https://www.learnreligions.com/eve-mother-of-all-the-living-701199

Filson, F. V. (1948). Theological exegesis. Journal of Bible and Religion, 16(4), 212-215. https://doi.org/10.1093/jaarel/XVI.4.212

Grammarly. (2019, May 8). Semicolon. Semicolons: A quick guide how to use a semicolon. Grammarly. Retrieved November 21, 2019, from https://www.grammarly.com/blog/semicolon/

94 Consortia Academia Publishing (A partner of Network of Professional Researchers and Educators) 
The figure of the woman in the Protoevangelium and the dispute of the sexes: An analysis on Genesis 3:15

Guzik, D. (2006). Study guide for Genesis 3. Blue letter Bible. Retrieved November 22, 2019, from https://www.blueletterbible.org/Comm/archives/guzik_david/StudyGuide_Gen/Gen_3.cfm

Jackson, W. (n. d.). Have you considered the consequences of sin? Christian courier. Retrieved November 9 , 2019, from https://www.christiancourier.com/articles/1554-have-you-considered-the-consequences-of-sin

Jewett, P. (1976). Original sin and fall of man. Southwestern Journal of Theology, 19. http://preachingsource.com/journal/original-sin-and-the-fall-of-man/

Kaiser, W. C. (1995). The messiah in the old testament. Zondervan.

McDowell, J. (1999). The new evidence that demands a verdict. Thomas Nelson.

Neusner, J. (1984). Our sages, God and Israel: An anthology of the Jerusalem Talmud. SP Books.

Paule. (2017, May 13). Nakedness and perspective: Understanding Genesis 3. Valid Ambiguity. Retrieved November 9, 2019, from http://validambiguity.com/2017/05/13/nakedness-perspective-understanding-genesis-3/

Sailus, C. (n. d.). Feminism in the 19th century: Women's rights, roles, and limits. Study.com. Retrieved December 1, 2019, from https://study.com/academy/lesson/feminism-in-the-19th-century-womens-rights-roles-and-limits.html

Schaeffer, D. (2018). Book review: Rousseau and the problem of human relations. Review of Politics, 79(4), 723-726. International Political Science Abstracts, 68(1), 152-152. https://doi.org/10.1177/0020834518068001205

Schlossman, B. L., \& York, H. J. (1976). Women in ancient art. Art Journal, 35(4), 345-351. https://doi.org/10.1080/00043249.1976.10793305

Shrives, C. (n. d.). Direct object: What is a direct object? Free English Grammar Tests. Retrieved November 21, 2019, from https://www.grammar-monster.com/glossary/direct_object.htm

Stevens, W. A. (1889). Grammatical exegesis. The Old and New Testament Student, 9(4), 198-206. https://doi.org/10.1086/470293

Vawter, B. (1973). A path through Genesis. Sheed and Ward.

Warner, J. M. (2016). Rousseau and the problem of human relations. Penn State Press. https://doi.org/10.26530/OAPEN_605032

Williams, G. (n. d.). Hobbes, Thomas: Moral and political philosophy. Internet Encyclopedia of Philosophy: An encyclopedia of philosophy articles written by professional philosophers. Retrieved December 1, 2019, from https://www.iep.utm.edu/hobmoral/\#H5 
Canete, J. J. O.

96 Consortia Academia Publishing (A partner of Network of Professional Researchers and Educators) 